\title{
Soft Tissue Sarcoma of the Abdomen and Thoracic Visceral Organs pN1 TNM Finding v8
}

National Cancer Institute

\section{Source}

National Cancer Institute. Soft Tissue Sarcoma of the Abdomen and Thoracic Visceral

Organs pN1 TNM Finding v8. NCI Thesaurus. Code C136745.

Soft tissue sarcoma of the abdomen and thoracic visceral org ans with lymph node involvement. (from AJCC 8th Ed.) 